\title{
THE IMPACT OF SECONDARY EDUCATION ON THE LEVEL OF FINANCIAL LITERACY: THE CASE OF SLOVAKIA
}

\author{
Patrik Böhm, Gabriela Böhmová, Viktória Šimková, Jana Gazdíková \\ University of Zilina, Slovakia \\ E-mail: patrik.bohm@fpedas.uniza.sk, gabriela.bohmova@fpedas.uniza.sk, \\ viktoria.simkova@fpedas.uniza.sk, jana.gazdikova@fpedas.uniza.sk
}

\begin{abstract}
Financial literacy, specifically its measurement and education in this field, is a very current topic. The main aim of this research was to find out whether secondary school education had a positive impact on the level of student's financial literacy and to identify other important factors that affected its level. All 363 first-year bachelor's students of the Faculty of Operations and Economic of Transport and Communications (FPEDAS), University of Zilina, Slovakia, took part in the research.

The research consisted of two parts - a questionnaire and a test. The questionnaire focused on demographic, educational, and socio-economic factors influencing students' financial literacy. The test included items aimed at finding out whether students could correctly define selected concepts of the financial area, whether they understood these concepts, and were able to analyze them.

The most important finding of the research was that the number of lessons dedicated to mathematics and financial literacy in secondary school did not have a statistically significant impact on the level of student's financial literacy. On the contrary, the level of financial literacy was correlated with the overall performance of the student at the secondary school and the type of secondary school the student attended. The research also aimed to verify the hypothesis that the student's study program affected the level of his or her financial literacy.

It turns out that increasing the number of mathematics or financial literacy lessons is not sufficient to improve financial literacy levels, but more important is teacher education, the content and form of the education and the effectiveness of the teaching process.
\end{abstract}

Keywords: financial literacy, secondary education, bachelor study program, tobit regression model

\section{Introduction}

In today's modern age, financial technologies are growing exponentially, changing the way people make payments and make decisions about their financial investments. In this context, it is important to understand the extent to which knowledge of finance influences financial decisions. Therefore, elementary financial literacy becomes a fundamental life skill. People have to make financial decisions at all ages: from children who learn to handle small amounts of money, through young people who earn their first money, to adults who buy their first home.

A good financial education makes everyday life easier and helps families and companies to plan their daily lives, whether they are short-term or long-term goals, and to prepare for unexpected situations. Obviously, adult people are more likely to use financial services provided by banks, such as mortgages, savings, and insurance. Using financial services increases their ability to make the right decisions that bring financial gain, and thus increase the overall quality of life. 
Patrik BÖHM, Gabriela BÖHMOVÁ, Viktória ŠIMKOVÁ, Jana GAZDÍKOVÁ. The impact of secondary education on the level of financial literacy: The case of Slovakia

PROBLEMS

OF EDUCATION IN THE $21^{\text {st }}$ CENTURY Vol. 79 , No. 1,2021

At the World Bank - IMF Group meetings in 2015, the World Bank Group and public and private partners made measurable commitments to achieve universal financial access by 2020 and help promote financial inclusion. Through this initiative, the World Bank Group have committed themselves to enable 1 billion people to access the transaction account through targeted interventions (The World Bank, 2020).

In 2012, G20 leaders recognized the important role of financial education policies with the approval of the OECD International Network for Financial Education High-level Principles on National Strategies for Financial Education. These Principles provided guidance to policymakers to develop evidence-based approaches to financial education, coordinated and tailored to all levels of the economy. At present, the 59 states worldwide are implementing national strategies by following the Principles. In less than five years, this number has more than doubled (OECD, 2015).

Within the European Union, there are countries such as Sweden and Denmark, which are at the top of the global financial literacy rankings, but also countries such as Romania and Portugal, that score below the global average. Based on these findings, the policy recommendations include the launch of financial literacy programs from an early age. Financial education should be developed by promoting programs tailored especially to the particular needs of young people, women, and low-income groups. The purpose of financial education should be to focus on people who make their big financial decisions, such as a loan, mortgage, or retirement investment (Batsaikhan \& Demertzis, 2018).

\section{PISA Testing}

Until the last decade of the 20th century, comparisons of OECD learning outcomes were based mainly on the number of years of compulsory education, which was not a reliable criterion for assessing students' capabilities and competencies. In 2005, OECD first reviewed surveys in 12 of its member countries. Consequently, in October 2008, the OECD established a subgroup of financial literacy measurement to address the need for internationally comparable financial literacy and capability surveys (OECD, 2011), and this effort resulted in the establishment of the International Student Assessment Program (PISA). The goal of PISA was to directly test students' knowledge and skills through internationally agreed metrics. The additional socioeconomic background was to be obtained by linking data from students, teachers, and schools (Schleicher, 2018).

PISA also examined students' experiences and knowledge about money and provided an overall picture of the ability of 15-year-olds to apply their acquired knowledge and skills in real situations involving financial matters and decisions. In recent decades, many countries around the world became increasingly concerned about the level of financial literacy of their citizens, especially students and young people.

The PISA defines financial literacy as (OECD, 2014, p. 33):

"Knowledge and understanding of financial concepts and risks, and the skills, motivation, and confidence to apply such knowledge and understanding in order to make effective decisions across a range of financial contexts, to improve the financial well-being of individuals and society, and to enable participation in economic life."

The PISA study (OECD, 2017) took into account three different aspects of financial literacy:

- content: money and financial transactions, planning and management, risk and return, and financial environment; 
Patrik BÖHM, Gabriela BÖHMOVÁ, Viktória ŠIMKOVÁ, Jana GAZDÍKOVÁ. The impact of secondary education on the level of financial literacy: The case of Slovakia

- processes: identification of financial information, analysis of information in the financial

context, evaluation of financial issues, understanding, and applying finance knowledge;

- contexts: education and work, household and family, personal finance, and company.

Prior to PISA financial literacy testing, little effort was made to collect data to compare the financial literacy of young people on a global scale. No systematic cross-country comparison or worldwide international research was conducted until 2012, but the PISA assessment has been carried out every three years since then. Financial literacy as part of PISA testing was only an optional part of the testing, though, therefore not all countries were involved. In the Slovak Republic, The Ministry of Education, Science, Research and Sport of the Slovak Republic, together with the National Institute of Certified Measurements of Education (NÚCEM), has been controlling and supervising the PISA testing since 2012.

In the first PISA financial literacy testing, the value of average performance was set at 500 points with a standard deviation of 100 points (OECD, 2014). In the next test cycle in 2015, fifteen countries from the world took part in the testing. Approximately 53,000 students were tested, representing almost 12 million 15-year-olds in the participating countries. Almost 1,540 fifteen-year-old Slovak students from 252 different schools took part in this testing. The best performing countries were China, Belgium, Canada, and Russia (OECD, 2017).

While the average performance of OECD countries in financial literacy remained at a comparable level of 489 points, which represented a statistically insignificant decrease by 11 points, the Slovak Republic achieved only 445 points in financial literacy PISA 2015 testing. It follows that the average score of Slovak students was 44 points below the average of the participating OECD countries and 25 points below its performance in 2012. Moreover, within the OECD countries, only Chile achieved a significantly lower performance than Slovakia. There may be several reasons why Slovak students have deteriorated in testing: the lack of consistent financial literacy education from pre-school to secondary school and the lack of teacher training. Parents should also be a role model in financial planning for their children, but we often encountered their irresponsible financial behavior (Brillová, 2017).

The PISA study also focused on aspects of the home or school environment that may affect performance. Understanding the context was one of the significant benefits of the PISA studies. Based on this information, it is possible to assess which of these aspects should be targeted and which should be eliminated so that the result of the educational process is a suitably educated individual ready to enter the labor market.

The socio-economic background of students is expressed by the so-called "student's social, economic and cultural status index" - ESCS. The ESCS index takes into account information on the student's parents' employment, their highest level of education and household material (including the availability of teaching aids, the number of books in the household, places to learn, etc.). The impact of socioeconomic status on students' school performance is a well-described phenomenon - higher socioeconomic status is usually associated with better school success (White, 1982). Although this influence is widespread in most education systems, the high degree of dependence of school performance on socio-economic status is undesirable - indicating that the education system does not provide equal opportunities for all students. Slovakia ranked among the countries with an above-average impact of the socioeconomic background on student performance in mathematics, reading, and natural sciences compared to the OECD average. In the area of financial literacy, these statistics were reaffirmed (Lučeničová, 2015). The findings of previous PISA evaluations were further confirmed in the recently published PISA 2018 test (OECD, 2020). The performance of Slovak students was the best of all three evaluations - the achieved score was 481 points, which was 35 points more than in 2015. However, the socio-economic differences were still alarming. Students with good socio-economic conditions achieved on average 101 points more than socio-economically disadvantaged students, which was an increase of 20 and 48 points compared to 2015 and 2012, respectively. 
Patrik BÖHM, Gabriela BÖHMOVÁ, Viktória ŠIMKOVÁ, Jana GAZDÍKOVÁ. The impact of secondary education on the level of financial literacy: The case of Slovakia

PROBLEMS

OF EDUCATION IN THE $21^{\text {st }}$ CENTURY Vol. 79 , No. 1, 2021

16

\section{Current Research on Financial Literacy}

One of the first studies that identified the characteristics of college students associated with the differences in the financial knowledge level was carried out by Danes and Hira in 1987. Six sociodemographic variables (marital status, gender, employment status, place of residence, income, and class status) explained $8.6 \%$ of the variance in overall financial management knowledge. Two of the socioeconomic variables were statistically significant in explaining the variance of overall financial literacy. Married students had, on average, $1.5 \%$ higher score on financial literacy than single students. In contrary to other research, female students had, on average, $0.6 \%$ points higher score on financial literacy than males.

Sohn et al. (2012) conducted a regression analysis to examine possible relation between agents of financial socialization, financial experience, attitudes toward money, and financial literacy of Korean adolescents. Monthly contributions, socializing agents, bank account holdings and access to money were related to financial literacy and accounted for $15 \%$ of the overall financial literacy variance. The monthly contribution was correlated with the financial literacy, as students with lower and higher contributions tended to have a reduced level of financial literacy compared to those in the middle allowance group by more than 3 percentage points. If students chose the media as their primary agent of financial socialization, they had a higher level of financial literacy by almost 3\% compared to those who chose a family as their primary agent of financial socialization. Also, owning a bank account increased financial literacy by more than $5 \%$.

The research of Falahati et al. (2011) revealed that girls showed better financial management and better spending behavior, while boys had better savings behavior. The multiple regression analysis employed by Sachitra and Wijesinghe (2018) explained $30 \%$ of variance in money management behavior by economic, social, and psychological factors. All three determinants proved to be statistically significant, with the psychological factor being the most powerful, followed by social and economic factors.

A study by Sabri et al. (2010) identified, in line with other research, children's experiences of discussing family finances with their parents as a significant factor in increasing their financial literacy. The regression model explained $4 \%$ of the total variance of financial literacy scores and included gender, ethnicity, place of origin, parent's education level and child consumers experience as independent variables. The effect of discussing finances with parents on financial literacy scores was estimated to be almost one percentage point.

Research by Agnew et al. (2018) used social cognitive theory of gender development as an area that suggested that different financial socialization of children was a potential cause of gender differences in financial literacy later in life. They provided evidence of gender differences in the frequency of discussions between children and parents related to financial attitudes.

Although it is obvious that financial education is of great importance, the literature does not offer clear evidence that education does increase financial literacy (Huston, 2009). While some research supported a significant positive correlation between financial education, financial literacy and financial outcomes (Fox et al., 2005; Lusardi, 2004), other studies suggested that financial education had no impact on improving financial knowledge of students (Mandell, 2006) or claimed that the costs of financial education programs outweighed their potential benefits (Willis, 2008). Arthur (2012) through an analysis of current and historical support for consumer financial literacy education argued that the choice we faced was not financial illiteracy or financial literacy, but the choice between complying with sustained competition requirements or critical financial literacy education.

Financial literacy education has become a global priority. Teachers now have more responsibility for educating students and there is a need to guide, educate and support educators more in this area (Blue et al., 2014). Amagir et al. (2017) evaluated the effectiveness of 
Patrik BÖHM, Gabriela BÖHMOVÁ, Viktória ŠIMKOVÁ, Jana GAZDÍKOVÁ. The impact of secondary education on the level of financial literacy: The case of Slovakia

educational programs and they showed that school financial education programs could improve the financial knowledge and attitudes of children and adolescents. Nevertheless, shortcomings in the financial management of individuals likely affect their well-being, and the mentioned mixed results only indicate that not all financial education programs contribute equally to the financial literacy of students (Huston, 2009). Therefore, since 2007, when the European Commission encouraged European Union Member States to support financial education, many institutions and programs have been gradually established in European countries to develop young people's financial literacy; including Slovak Republic.

\title{
Financial Education in Slovak Republic
}

The Government of the Slovak Republic responded to the European Commission's call by approving a Draft Strategy for Education in Financial Matters and Personal Finance Management. Based on this document, the National Standard of Financial Literacy (NSFL) was approved. It focused on such topics as financial responsibility, safeguarding money, credit and debt, saving and investment, risk management and insurance, but in addition to these financial topics, it integrated consumer education, anti-corruption education, business education, as well as education against fraud in the use of public resources (NBS, 2019).

The first survey of financial literacy of the population of the Slovak Republic was conducted in 2007 by the Slovak Banking Association (SBA). Respondents answered 10 questions with an overall success rate of $56 \%$. The highest success rates were achieved by university-educated consumers, self-employed persons and respondents aged 26 to 45 years. On the other hand, the lowest success rate was achieved by the unemployed, the responders aged 66 to 75 and persons with basic education. The survey revealed that even though bank clients had enough information on the financial products and services offered, they did not understand the basic financial concepts and were therefore unable to analyze and evaluate them (NBS, 2019). In March 2018, the European Banking Federation coordinated a large survey of financial literacy in Slovakia. Total of 1,600 students took part in testing, which revealed that respondents had a low ability to analyze and process information due to a misunderstanding of the basic financial concepts. For example, respondents did not know the differences between payment cards or could not choose the most beneficial term deposit from the two products.

DOLCETA (Developing of On-line Consumer Education Tools for Adults) is a project funded by the European Commission that targets at the trainers and teachers who educate adults as well as primary and secondary school students (DOLCETA). "Know your money" is a project of the Slovenska sporitelna foundation, that created an e-learning program aimed at high school students. Later, it also focused on the development of financial literacy among primary school students and the improvement of the knowledge and skills of teachers (SLSP, 2020). A large range of both long-term and short-term projects has been organized by a nonprofit educational organization Junior Achievement Slovakia: Me and Money, Business Basics, Applied Economy, More than Money, and Innovation Camp, to name a few. The Slovak programs "More than money" and "Me and money", which were created in accordance with the National Standard of Financial Literacy, test the financial literacy of primary and secondary school students. The measure of success is the comparison of the entrance and exit test results. Only $10 \%$ of high school students and only $3 \%$ of primary school students successfully passed the entrance test in the 2016/2017 school year. It can therefore be assumed that students did not come from a family environment with knowledge of finance and these shortcomings were not eliminated during the first years of study.

Based on the results of PISA 2012, PISA 2015 and SBA 2007, a survey of financial literacy of students at the Slovak University of Technology was conducted in 2007 and 2017. Students already took part in financial education program at least at secondary school and

\author{
PROBLEMS \\ OF EDUCATION \\ IN THE $21^{\text {st }}$ CENTURY \\ Vol. 79 , No. 1,2021 \\ 17
}


Patrik BÖHM, Gabriela BÖHMOVÁ, Viktória ŠIMKOVÁ, Jana GAZDÍKOVÁ. The impact of secondary education on the level of financial literacy: The case of Slovakia

PROBLEMS

OF EDUCATION

IN THE $21^{\text {st }}$ CENTURY

Vol. 79 , No. 1,202

had practical experience with the use of some financial products. Consequently, the survey aimed to find out if their previous financial education affected their financial literacy. In a survey conducted in 2017, students achieved, on average, worse results than in 2007. Only $10 \%$ of respondents had a relatively good level of financial literacy, while $50 \%$ of respondents showed financial knowledge only at a basic level. This implies that despite financial education in primary and secondary schools, financial literacy has declined - as also the PISA survey showed (Janakova \& Fabova, 2017).

The analysis of the state of financial education in the Slovak Republic indicates that the development of the student's financial culture is almost absent and is not accepted by students. Financial literacy is not internalized by the students, they consider financial literacy as an obligation rather than as an essential element that will affect their lives. Despite the National Standard of Financial Literacy and the emergence of many financial literacy programs, in Slovakia there is no uniform syllabus of the financial education in primary and secondary schools. Schools themselves decide on the form and content of education in this area.

\section{Research Problem and Research Questions}

In the school year 2019/2020, students who were tested in the PISA2015 testing began attending the first year of bachelor's studies at the Faculty PEDAS. In the above-mentioned PISA 2015 study, the Slovak Republic achieved results in the area of financial literacy below the average of the participating OECD countries. Based on this study, $34.7 \%$ of students have not been able to solve financial tasks and put into practice financial issues and problems in basic contexts. In this research, the financial literacy of high school graduates, who are currently first-year university students, is tested. Testing of university students receives little attention in national and international research, and this study fills a gap in this area.

Based on the analysis of previous work, it is concluded that Slovakian university students are not adequately tested in the field of financial literacy. Anyway, their financial decisions have undoubtedly a big impact on their lives. They are of legal age, many of them work occasionally or have a part-time job and make their own decisions. Moreover, some students live in a dorm or have their own housing and are forced to manage their finances efficiently. It is therefore important to examine how students are prepared to make important financial decisions and what factors affect their decisions.

The main aim of the research was to find out whether education at secondary school positively influenced the students' level of financial literacy and to identify other factors influencing the level of their financial literacy. To meet the research objectives, the following hypotheses were formulated (Table 1): 
Patrik BÖHM, Gabriela BÖHMOVÁ, Viktória ŠIMKOVÁ, Jana GAZDÍKOVÁ. The impact of secondary education on the level of financial literacy: The case of Slovakia

Table 1

List of the Research Hypotheses

\begin{tabular}{|c|c|}
\hline \multirow[b]{2}{*}{$\mathrm{H}_{\text {Math\&FL }}$} & $\begin{array}{l}\text { Students with a higher number of mathematics and financial literacy lessons at secondary school } \\
\text { have a higher level of financial literacy. }\end{array}$ \\
\hline & $\begin{array}{l}\text { Rationale: Since secondary schools can adjust the number of mathematics and financial literacy } \\
\text { lessons in the last two years of study, it is expected that the skills that students acquire in these } \\
\text { classes are reflected in a better level of financial literacy. }\end{array}$ \\
\hline \multirow[b]{2}{*}{$\mathrm{H}_{\text {StudyProgram }}$} & Students of study programs EaME, FM, and EBaM have a higher level of financial literacy. \\
\hline & $\begin{array}{l}\text { Rationale: The bachelor degree programs Economics and Management of Enterprise (EaME), } \\
\text { Financial Management (FM) and Electronic Business and Management (EBaM) include economic } \\
\text { subjects, therefore it is assumed that these students are more interested in economics and, } \\
\text { consequently, have better knowledge of financial literacy. }\end{array}$ \\
\hline \multirow[b]{2}{*}{$\mathrm{H}_{\text {Gender }}$} & Women achieve lower level of financial literacy than men. \\
\hline & $\begin{array}{l}\text { Rationale: Most research shows that one of the most important factors influencing the level of } \\
\text { financial literacy is the gender of students, with women achieving a lower level of financial literacy } \\
\text { than men. }\end{array}$ \\
\hline \multirow[b]{2}{*}{$\mathrm{H}_{\text {School\&Study }}$} & $\begin{array}{l}\text { Grammar school students and students with better overall academic results in high school perform } \\
\text { better in the field of financial literacy. }\end{array}$ \\
\hline & $\begin{array}{l}\text { Rationale: Study at grammar schools is generally focused and aims to develop students' } \\
\text { comprehensive skills, while at vocational schools, study is usually highly specialized. Therefore, the } \\
\text { level of financial literacy of grammar school students is expected to be higher than that of vocational } \\
\text { school students. }\end{array}$ \\
\hline \multirow[b]{2}{*}{$\mathrm{H}_{\text {UseOfBankServices }}$} & The use of selected banking products has a positive impact on the level of financial literacy. \\
\hline & $\begin{array}{l}\text { Rationale: It is assumed that students who use more banking products have a better overview of } \\
\text { financial management. Therefore, this research expects that the use of selected banking products } \\
\text { has a positive impact on the results in FL testing. }\end{array}$ \\
\hline
\end{tabular}

Research Methodology

\section{General Background}

While previous research highlighted that financial literacy could be affected by demographic, socio-economic, or other factors, this research focused mainly on the influence of the secondary education. Each student filled out a questionnaire and consequently performed a financial literacy test.

The questionnaire contained nineteen questions focused on demographic, educational, and socio-economic factors that could affect students' financial literacy, as they often appeared to be statistically significant predictors of financial literacy in previous studies - the students' gender, their study program, the average results during their study at secondary school, the type of secondary school they attended, and the banking products they used.

The test focused on the evaluation of the general knowledge of students in the field of financial literacy, taking into account the financial market of the Slovak Republic, if necessary. It contained thirteen items. The students received one point for each correct answer and his or her overall success ratio was calculated consequently. The items of the financial literacy test were an intersection of the tasks of PISA 2015 tests, the financial literacy surveys in Slovakia and the experience from teaching subjects focused on financial literacy at the faculty PEDAS. Only items with the possibility of one correct answer were included in the test. Open-ended items were not included in the test either. 
Patrik BÖHM, Gabriela BÖHMOVÁ, Viktória ŠIMKOVÁ, Jana GAZDÍKOVÁ. The impact of secondary education on the level of financial literacy: The case of Slovakia

PROBLEMS

OF EDUCATION

IN THE $21^{\text {st }}$ CENTURY

Vol. 79 , No. 1,2021

Since the research focused on the students of the University of Zilina, some relevant specifics of the Slovak education system are presented. In Slovakia, secondary schools are divided into grammar schools (which provide general education and prepare students for university studies), business schools (which prepare graduates with a broad general vocational education, necessary for the performance of business and entrepreneurial functions), and other vocational schools. Grading of students in schools in Slovakia has five levels:

- 1 - excellent,

- 2 - commendable,

- 3 - good,

- 4 - sufficient,

- 5 - insufficient.

Based on the average grades during secondary school study, students were divided into three groups: average grade up to 1.5, average grade between 1.5 and 2.0 and average grade more than 2.0.

The research monitored the number of lessons of subjects Mathematics and Financial Literacy in the last two years of study at the secondary school and the average grade of compulsory subjects in the last year of study. Students also answered the question whether they had their own bank account, payment card, and for how long they used them. Students could choose from the following options: I use a current account, debit card, credit card, savings, term deposit, building savings, and internet banking.

The research took place in October 2019 in mathematics lessons. Students had 10 minutes to complete a questionnaire and 15 minutes to pass a financial literacy test.

\section{Sample}

The small sample of 50 students was first pre-tested to see if the test items were clearly defined and to determine the amount of time required to complete the test. Consequently, all 363 first-year bachelor degree students were tested.

Students of the Faculty FPEDAS were divided into two groups based on their specialization - transport or economics. Transport study programs are focused on the application of theoretical knowledge in a specific area of transport. On the other hand, the study of economics helps students to prepare for jobs in the economic, financial and social systems of society. Transport bachelor programs were Road Transport (RoadT), Railway Transport (RailT), Air Transport (AirT), Water Transport (WaterT), and Forwarding and Logistics (FaL). Economic bachelor programs were Electronic Business and Management (EBaM), Economics and Management of Enterprise (EaME), and Financial Management (FM). As there were only a few Water Transport students and their study program was similar to the Railway Transport, students of these two study programs were combined into one group.

Most of the surveyed students were female, but large differences were found between study programs, as shown in Table 2. Approximately half of the students came from the region of Zilina and half from other regions of Slovakia. Again, large differences between study programs were found - for example, almost 90\% students of Air Transport program came from other regions of Slovakia. Only $16.8 \%$ of students lived in cities with population less than 10000 and $24.5 \%$ lived in cities with population over 30000 . Majority of students lived in cities with population between 10000 and 30000 inhabitants. Over $60 \%$ of students studied at grammar schools or business academies. However, vocational school students accounted for $72.2 \%$ in Road Transport and 68\% in Railway Transport study programs. Only small differences were found between study programs in terms of the average grade of students at high school, with $48 \%$ of students recording average grade between 1.5 and $2.0,27.8 \%$ recording average grade of less than 1.5 and $23.7 \%$ more than 2.0 . 
Patrik BÖHM, Gabriela BÖHMOVÁ, Viktória ŠIMKOVÁ, Jana GAZDÍKOVÁ. The impact of secondary education on the level of financial literacy: The case of Slovakia

Overall, it can be concluded that the surveyed students formed a representative sample

PROBLEMS

OF EDUCATION

IN THE $21^{\text {st }}$ CENTURY

Vol. 79, No. 1, 2021 of students from Slovakia at technical and economic universities, because students of all types of secondary schools from different regions were included and both genders were equally represented.

Table 2

Sociodemographic Characteristics of the Sample

\begin{tabular}{lcccccccc}
\hline \multirow{2}{*}{ Variable } & \multicolumn{7}{c}{ Study Program } \\
\cline { 2 - 8 } & RoadT & EBaM & FM & FaL & EaME & AirT & RailT & All Students \\
\hline Gender (\%) & 77.8 & 29.3 & 23.4 & 51.7 & 22.5 & 79.2 & 84.0 & 45.7 \\
Male & 22.2 & 70.7 & 76.6 & 48.3 & 77.5 & 20.8 & 16.0 & 54.3 \\
Female & & & & & & & & \\
\hline Region (\%) & 19.4 & 81.0 & 70.2 & 48.3 & 67.4 & 10.4 & 20.0 & 51.2 \\
Zilina & 80.6 & 19.0 & 29.8 & 51.7 & 32.6 & 89.6 & 80.0 & 48.3 \\
Other & & & & & & & & \\
\hline City Size - Population (\%) & 61.1 & 65.5 & 70.2 & 58.3 & 66.3 & 29.2 & 48.0 & 16.8 \\
Less than 10 000 & 16.7 & 13.8 & 21.3 & 11.7 & 14.6 & 20.8 & 28.0 & 58.7 \\
10 000 - 30 000 & 22.2 & 20.7 & 8.5 & 30.0 & 19.1 & 50.0 & 24.0 & 24.5 \\
More than 30 000 & & & & & & & & \\
\hline Type of Secondary School (\%) & 27.8 & 63.8 & 78.7 & 53.3 & 77.5 & 60.4 & 32.0 & 61.2 \\
Grammar School / Business & & & & & & & & \\
Academy & 72.2 & 36.2 & 21.3 & 46.7 & 22.5 & 39.6 & 68.0 & 38.8 \\
Vocational School & 13.9 & 13.8 & 31.9 & 25.0 & 34.8 & 39.6 & 32.0 & 27.8 \\
\hline Secondary School Average Grade (\%) & & & & & & & \\
Less than 1.5 & 55.6 & 51.7 & 53.2 & 40.0 & 49.4 & 47.9 & 40.0 & 48.5 \\
1.5 - 2.0 & 30.6 & 34.5 & 14.9 & 35.0 & 15.7 & 12.5 & 28.0 & 23.7 \\
More than 2.0 & & & & & & & \\
\hline
\end{tabular}

\section{Data Analysis}

Data analysis was performed in two steps. In the first step, the students' success ratio was calculated. In the second step, tobit regression model was used to determine which factors influence the financial literacy of students. The tobit model, also called the censored regression model, was designed to estimate the linear relation between variables when there was left or right censorship in the dependent variable (also known as lower and upper censorship). An integral part of the second step was the verification that the selected factors were not linearly dependent and that there was no multicollinearity present, using variance inflation factor. All control variables used in the regression analysis are shown in Table 3.

For data processing, $\mathrm{R}$ statistical language and environment for statistical computing was used (R Core Team, 2013). For censored regression calculation, censReg package was used (Henningsen, 2019). 
Patrik BÖHM, Gabriela BÖHMOVÁ, Viktória ŠIMKOVÁ, Jana GAZDÍKOVÁ. The impact of secondary education on the level of financial literacy: The case of Slovakia

OF EDUCATION

IN THE $21^{\text {st }}$ CENTURY Vol. 79 , No. 1, 202

\section{Table 3}

Control Variables Used in Regression Analysis

\begin{tabular}{|c|c|c|}
\hline Control Variable & Acronym & Value (Encoding) \\
\hline Air Transport student & AirT & $\begin{array}{l}\text { Yes - } 1 \\
\text { No-0 }\end{array}$ \\
\hline Railway Transport or Water Transport student & RailT & $\begin{array}{l}\text { Yes }-1 \\
\text { No }-0\end{array}$ \\
\hline Economics and Management of Enterprise student & EaME & $\begin{array}{l}\text { Yes }-1 \\
\text { No }-0\end{array}$ \\
\hline Financial Management student & $\mathrm{FM}$ & $\begin{array}{l}\text { Yes }-1 \\
\text { No }-0\end{array}$ \\
\hline Electronic Business and Management student & EBaM & $\begin{array}{l}\text { Yes }-1 \\
\text { No }-0\end{array}$ \\
\hline Forwarding and Logistics student & FaL & $\begin{array}{l}\text { Yes }-1 \\
\text { No }-0\end{array}$ \\
\hline Gender & GenderFem & $\begin{array}{l}\text { Female - } 1 \\
\text { Male - } 0\end{array}$ \\
\hline Type of secondary school & SchoolVoc & $\begin{array}{l}\text { Vocational school }-1 \\
\text { Grammar or business school }-0\end{array}$ \\
\hline Financial literacy lessons in the last two years of study & FinLit & $\begin{array}{l}\text { Total number of financial literacy } \\
\text { lessons per week }\end{array}$ \\
\hline $\begin{array}{l}\text { Mathematics lessons in the last two years of study (including } \\
\text { optional mathematical subjects) }\end{array}$ & Math & $\begin{array}{l}\text { Total number of mathematics lessons } \\
\text { per week }\end{array}$ \\
\hline Average grade between 1.5 and 2.0 & Grade1.5 & $\begin{array}{l}\text { Yes }-1 \\
\text { No }-0\end{array}$ \\
\hline Average grade more than 2.0 & Grade2.0 & $\begin{array}{l}\text { Yes }-1 \\
\text { No }-0\end{array}$ \\
\hline Student has a savings account or some form of savings & ServSav & $\begin{array}{l}\text { Yes }-1 \\
\text { No }-0\end{array}$ \\
\hline Student has building savings & ServBSav & $\begin{array}{l}\text { Yes }-1 \\
\text { No }-0\end{array}$ \\
\hline Student has a term deposit & ServTDep & $\begin{array}{l}\text { Yes }-1 \\
\text { No }-0\end{array}$ \\
\hline Student uses debit card & ServDCard & $\begin{array}{l}\text { Yes }-1 \\
\text { No }-0\end{array}$ \\
\hline Student uses credit card & ServCCard & $\begin{array}{l}\text { Yes }-1 \\
\text { No }-0\end{array}$ \\
\hline Student uses internet banking & ServlB & $\begin{array}{l}\text { Yes - } 1 \\
\text { No-0 }\end{array}$ \\
\hline
\end{tabular}


Patrik BÖHM, Gabriela BÖHMOVÁ, Viktória ŠIMKOVÁ, Jana GAZDÍKOVÁ. The impact of secondary education on the level of financial literacy: The case of Slovakia

\section{Research Results}

A total of 363 university students participated in the research on the level of financial literacy. The average success rate of the test was $56.18 \%$, which implied average level of financial literacy. Three students correctly answered all test items, while one student did not have a single correct answer. Descriptive statistics of students' financial literacy scores are presented in Table 4.

\section{Table 4}

Overall Success Rate - Percentage of Successful Answers

\begin{tabular}{llcccc}
\hline Students & Min & Max & Med & Mean & SD \\
\hline 363 & 0 & 100 & 53.85 & 56.18 & 17.97 \\
\hline
\end{tabular}

Tobit Ordinary Least Squares Regression Analysis

Tobit ordinary least squares regression analysis (OLS) was employed to determine the level of influence of socio-economic indicators on the level of students' financial literacy. The model was tested for multicollinearity using variance inflation factor (VIF) criteria and since all variables had VIF within acceptable limits (less than 5), it could be concluded that multicollinearity was not present in the model. Table 5 summarizes the multiple regression analysis results.

\section{Table 5}

\section{OLS Regression Analysis Results}

\begin{tabular}{lllll}
\hline Independent variables & Estimate & SD & t-value & $\boldsymbol{p}$ \\
\hline (Intercept) & 53.41 & 4.62 & 11.56 & $<.001^{* * *}$ \\
\hline AirT & 9.08 & 3.71 & 2.45 & $.015^{*}$ \\
\hline RailT & 9.79 & 4.24 & 2.31 & $.021^{*}$ \\
\hline EaME & 9.84 & 3.54 & 2.78 & $.006^{* *}$ \\
\hline FM & 5.70 & 3.95 & 1.44 & .150 \\
\hline EBaM & 2.04 & 3.59 & 0.57 & .570 \\
\hline FaL & 5.92 & 3.52 & 1.68 & $.093^{*}$ \\
\hline GenderFem & -7.08 & 1.98 & -3.57 & $<.001^{* * *}$ \\
\hline SchoolVoc & -4.52 & 1.93 & -2.34 & $.020^{*}$ \\
\hline FinLit & -1.46 & 1.17 & -1.25 & .211 \\
\hline Math & 0.27 & 0.37 & 0.74 & .461 \\
\hline Grade1.5 & -4.22 & 2.05 & -2.06 & $.040^{*}$ \\
\hline Grade2.0 & -6.05 & 2.50 & -2.42 & $.016^{*}$ \\
\hline ServSav & 2.09 & 1.87 & 1.12 & .263 \\
\hline ServBSav & 2.52 & 0.10 & .923 \\
\hline ServTDep & 0.25 & 3.45 & 1.11 & .267 \\
\hline ServDCard & 3.84 & 2.50 & 1.54 & .124 \\
\hline ServCCcard & 3.85 & 2.41 & -2.49 & $.013^{*}$ \\
\hline ServIB & -6.00 & 2.13 & 2.37 & $.018^{*}$ \\
\hline *te: $p<$ & 5.05 & & &
\end{tabular}

Note: ${ }^{* * *} p<.001,{ }^{* *} p<.01,{ }^{*} p<.05,{ }^{*} p<.1$, 
Patrik BÖHM, Gabriela BÖHMOVÁ, Viktória ŠIMKOVÁ, Jana GAZDÍKOVÁ. The impact of secondary education on the level of financial literacy: The case of Slovakia

IN THE $21^{\text {st }}$ CENTURY Vol. 79 , No. 1, 2021

The model accounted for $26 \%$ of the total variance in financial literacy and since $p$-value of $\mathrm{F}$ test was smaller than .001 , the model was statistically significant. Table 5 shows $p$-values for all control variables. In total, eighteen explanatory variables were included in the model, of which nine were statistically significant at the significance level of at least .05 and one variable at the significance level .1. Most significant predictors of relative scores on financial literacy included study program, gender, and high school grade. On contrary, seven predictors were not statistically significant. The obtained empirical specification of the model was:

$$
\begin{gathered}
\text { SuccessRate } \\
=53.4+9.08 * \text { AirT }+9.79 * \text { RailT }+9.83 * \text { EaME }+5.70 * \text { FM }+2.04 \\
* \text { EBaM+5.92*FaL-7.08*GenderFem-4.52*SchoolVoc-1.46 } \\
\text { *FinLit }+0.27 * \text { Math-4.22Grade1.5-6.05*Grade2.0 }+2.09
\end{gathered}
$$

*ServSav+0.25*ServBuildSav+3.84*ServTermDep+3.85*ServDC-6.00*ServCC+5.05*ServIB

The Influence of the Number of Hours of Mathematics and Financial Literacy Lessons on the Student's Level of Financial Literacy

First, the research examined whether the number of mathematics and financial literacy lessons that students completed during their secondary school studies had a positive impact on their knowledge of financial literacy. The research showed that there was no such statistically significant correlation. The number of math lessons had positive impact on the success rate in the financial literacy, as one hour of math lessons per week resulted in a $0.27 \%$ increase in success rate. On contrary, number of financial literacy lessons had negative impact on the student's performance, because one hour of financial literacy lessons per week led to a reduction in the student's success rate by $1.46 \%$. However, both differences were not statistically significant at the level of .05 , hence the OLS model did not reveal any statistically significant impact of the number of hours of mathematics and financial literacy lessons on students' knowledge in the monitored area. Success rate of students according to hours of financial literacy and mathematics is presented in Figure 1, which also confirms that there is no apparent correlation.

\section{Figure 1}

Dependence of the Success Rate on the Number of Math and Financial Literacy Lessons

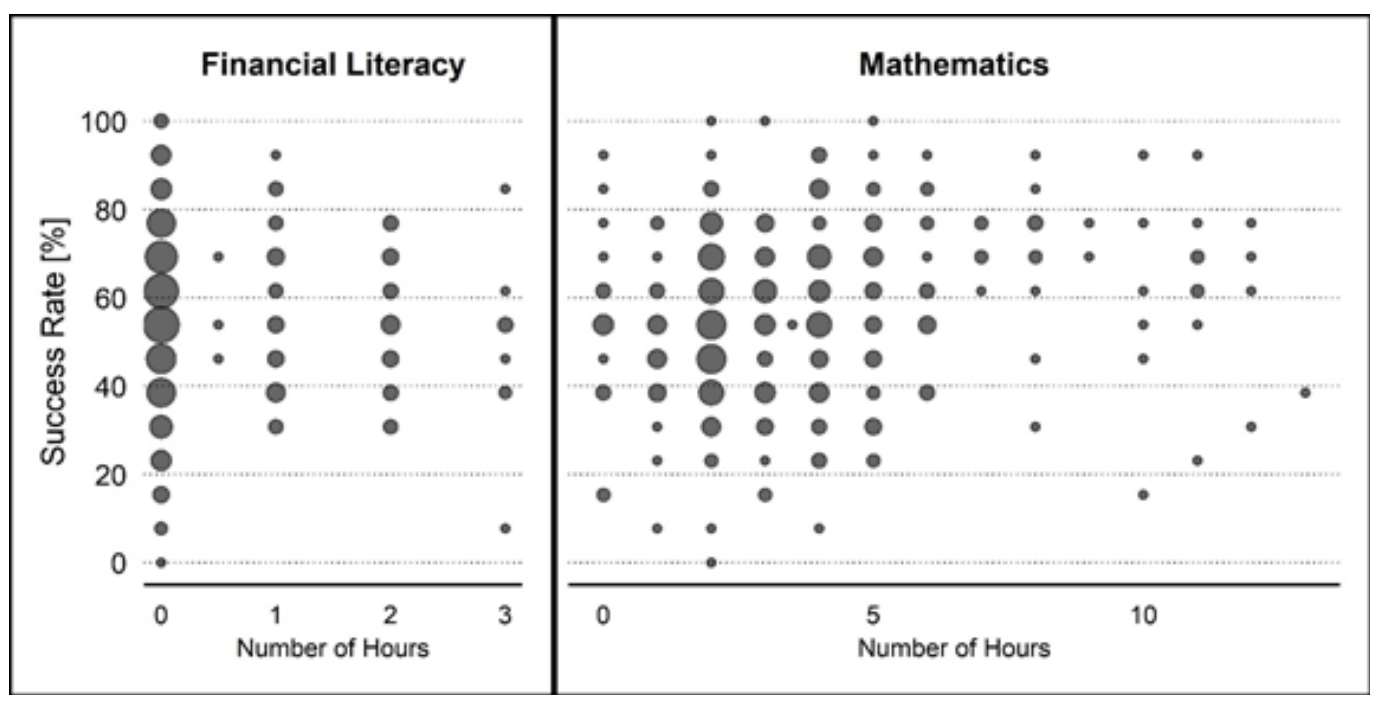


Patrik BÖHM, Gabriela BÖHMOVÁ, Viktória ŠIMKOVÁ, Jana GAZDÍKOVÁ. The impact of secondary education on the level of financial literacy: The case of Slovakia

\section{The Influence of the Study Program on the Student's Level of Financial Literacy}

The lowest average value of success rate was achieved by students of Road Transport study program. Other study programs were compared with respect to this study program. Figure 2 shows the success rate of students depending on the study program they attended. In this Figure 2, study programs are ordered according to the growing median.

\section{Figure 2}

Dependence of the Success Rate on the Study Program



The highest average value of success rate was achieved by students of the Economics and Management of Enterprise, closely followed by the students of the Railway Transport and Air Transport study programs. The difference was statistically significant at the level of significance .05 , students of these three study programs achieved $9.84 \%, 9.79 \%$, and $9.08 \%$ higher success rate than students of Road Transport program, respectively. Students of Forwarding and Logistics study program achieved $5.92 \%$ higher success rate than students of Road Transport program, this difference was statistically significant only at the level of significance .10, though. Students of two remaining study programs - Financial Management and Electronic Business and Management - achieved $5.70 \%$ and $2.04 \%$ higher success rate than students of Road Transport program, respectively. However, these differences were not statistically significant since p-values of FM and EBaM coefficients were greater than .05 .

No statistically significant differences were observed when comparing results of students of economic and transport study programs. Overall, students of transport study programs scored better than students of economics programs ( $57 \%$ vs. $55.5 \%)$

\section{The Influence of Student's Gender on the Student's Level of Financial Literacy}

The multiregression analysis showed that, on average, women's success rate was 7.08 $\%$ lower than men's (Figure 3). p-value of the GenderFem coefficient was less than .001, so this relation was strongly statistically significant. Since this p-value was the smallest of all coefficients in OLS model, it follows that the gender factor was the most significant coefficient of all observed indicators of the evaluated regression model. 
Patrik BÖHM, Gabriela BÖHMOVÁ, Viktória ŠIMKOVÁ, Jana GAZDÍKOVÁ. The impact of secondary education on the level of financial literacy: The case of Slovakia

PROBLEMS

OF EDUCATION IN THE $21^{\text {st }}$ CENTURY Vol. 79 , No. 1,2021

Figure 3

Dependence of the Success Rate on Gender



The Influence of Students' Overall Secondary School

Performance on their Financial Literacy

Students who attended grammar school or business academy had on average $4.52 \%$ points better scores than students who attended vocational schools. This difference was statistically significant at the level of significance .05 . These results imply that the type of secondary school that students attended affected their financial literacy (Figure 4).

\section{Figure 4}

Dependence of the Success Rate on the Type of High School and on the High School Average Grade




Patrik BÖHM, Gabriela BÖHMOVÁ, Viktória ŠIMKOVÁ, Jana GAZDÍKOVÁ. The impact of secondary education on the level of financial literacy: The case of Slovakia

PROBLEMS

OF EDUCATION

IN THE $21^{\text {st }}$ CENTURY

Vol. 79, No. 1, 2021

Tested students were divided into three groups based on the average results during their study at secondary school. Students with average secondary school ratings between 1.5 and 2.0 performed $4.22 \%$ worse than students with average grade less than 1.5. Students with average grade higher than 2.0 scored $6.04 \%$ lower than students in the best group. Both differences were statistically significant at the level of significance .05 . Based on this fact, it can be concluded that students' financial literacy was strongly correlated with their academic performance in secondary school. The better the overall results of the student, the better his knowledge in the field of financial literacy. Both graphs at Figure 4 clearly show the influence of the type of secondary school and the students' average grade at secondary school on their financial literacy knowledge.

\section{The Influence of the Usage of Selected Banking Services on the Student's Level of Financial Literacy}

Six selected banking services were observed in order to determine whether their usage affected students' financial literacy. Five of the services, Savings, Building Savings, Term Deposit, Use of Debit and Credit Card, and Use of Internet banking, had a positive impact on students' success rate. Only the use of internet banking proved to be statistically significant, though. On average, students who used internet banking scored 5.05\% higher than students who did not use it. Even though Savings, Building Savings, Term Deposit, and Use of Debit Card also had positive impact on success rate by $2.09 \%, 0.25 \%, 3.84 \%$, and $3.85 \%$, this impact was not statistically significant.

The differences between the performance of students who used selected types of banking services and those who did not use them are presented in Figure 5.

\section{Figure 5}

Dependence of the Success Rate on the Type of Bank Service Used

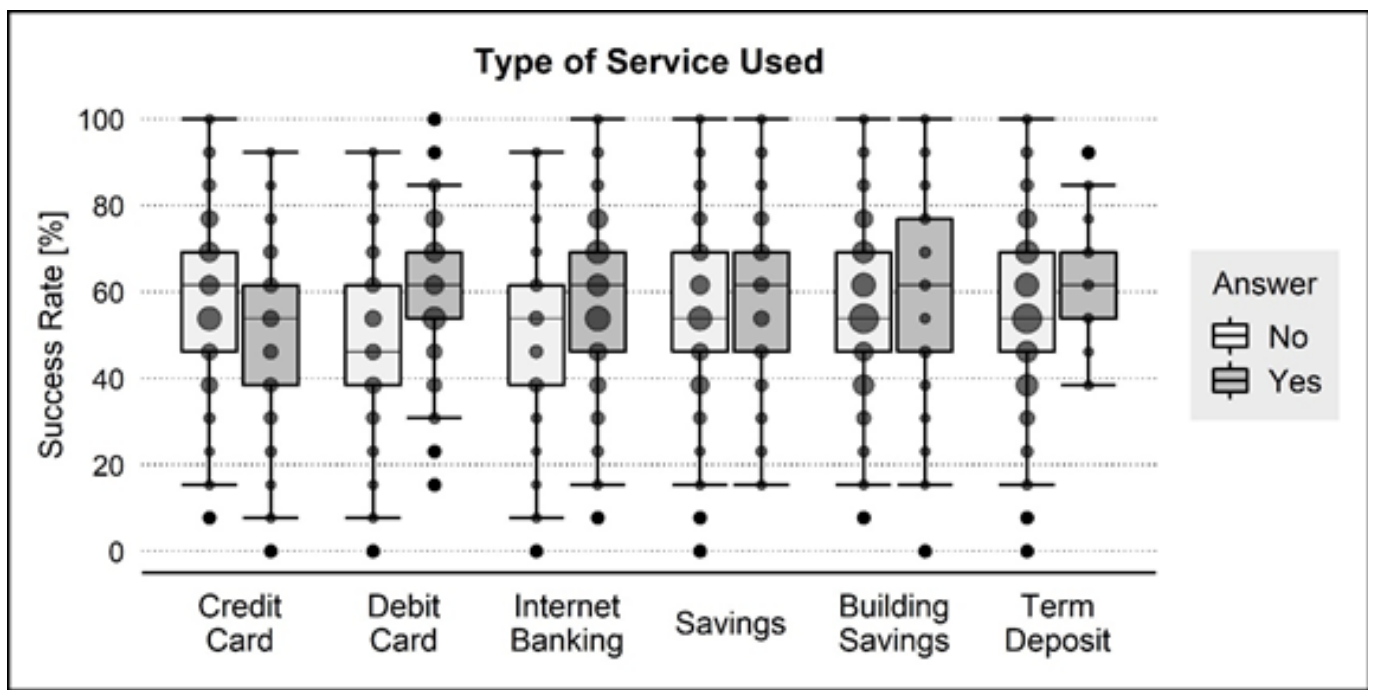

\section{Discussion}

This research focused on factors influencing the level of financial literacy. Students with a higher number of mathematics and financial literacy lessons were expected to achieve a higher level of financial literacy knowledge. This research, however, did not confirm this assumption. 
Patrik BÖHM, Gabriela BÖHMOVÁ, Viktória ŠIMKOVÁ, Jana GAZDÍKOVÁ. The impact of secondary education on the level of financial literacy: The case of Slovakia

PROBLEMS

OF EDUCATION IN THE $21^{\text {st }}$ CENTURY Vol. 79, No. 1, 2021

28

The most important findings of the research included that the number of hours of mathematics and the number of hours of financial literacy in secondary school did not have a statistically significant impact on the level of financial literacy.

Although it is obvious that financial education is of great importance, the literature does not offer clear evidence that education does increase financial literacy. While many papers supported a significant positive correlation between financial education, financial literacy and financial outcomes (Fox et al., 2005; Lusardi 2004), other studies suggested that financial education had no effect on improving financial knowledge scores of students (Mandell, 2006) or claimed that the costs of financial education programs outweighed their potential benefits (Willis, 2008). These mixed results suggest that not all financial education programs are equally effective. This research also did not demonstrate the impact of mathematics and financial teaching on students' knowledge of financial literacy. Nevertheless, shortcomings in the financial management of individuals likely affect their well-being, and the mentioned mixed results only indicate that not all financial education programs contribute equally to the financial literacy of students (Huston, 2009).

Teachers now have more responsibility for educating students and there is a need to guide, educate and support educators more in this area (Blue et al., 2014). Amagir et al. (2017) evaluated the effectiveness of educational programs and interventions in the field of financial literacy for children and adolescents. A promising teaching method in primary and secondary school is "experiential learning". In higher education, emphasis should be placed on the specific "life events" of students. It turns out that increasing the level of financial literacy cannot be easily achieved by increasing the number of hours of mathematics education or financial literacy education, but by improving the learning content, changing the form of education, and higher efficiency of the teaching process.

On the contrary, this study showed that the type of school and the average grades during high school studies had a statistically significant positive impact on the level of financial literacy. Students who attended grammar or business school scored, on average, 4.52\% higher than students who attended vocational schools. Similar results were presented in a study by Ansong and Gyensare (2012), who adopted a correlational research to examine the relation between socioeconomic variables and financial literacy of 250 undergraduate and postgraduate students of a public university in Ghana. Business students achieved better results than nonbusiness students.

Students with average secondary school rating less than 1.5 achieved the best results in the financial literacy test. Based on these results, it can be concluded that students' financial literacy is better for students with better academic performance during secondary school. This fact is in accordance with studies of Bhushan and Medury (2013) and Chen and Volpe (2002). Bhushan and Medury (2013) showed, that level of financial literacy is positively related to education and income level indicating that financial literacy level increases with increase in education and income level. Higher test performance is also more likely if the participants have higher educational aspirations, as suggested by Rudeloff (2019).

One of the few studies that observed a correlation between students' financial literacy and their study program was a study of Kozina and Ponikvar (2014), which revealed that the likelihood of students' confidence in their financial management capability and knowledge was significantly larger for students who specialize in economics or business studies. Based on these results, it was reasonable to expect that students in the EaME, FM, and EBaM study programs achieve better results in financial literacy tests. Another reason why above-average results in the field of financial literacy were expected for these students was the fact that they are mainly graduates of grammar schools and business academies with good academic results. This hypothesis was only partially confirmed, though. Students of the EaME study program demonstrated the highest level of financial literacy, while students of the FM and EBaM study programs reached only an average level. 
Patrik BÖHM, Gabriela BÖHMOVÁ, Viktória ŠIMKOVÁ, Jana GAZDÍKOVÁ. The impact of secondary education on the level of financial literacy: The case of Slovakia

PROBLEMS

OF EDUCATION

IN THE $21^{\text {st }}$ CENTURY

Vol. 79, No. 1, 2021

EaME students made up the largest part of the sample (almost 25\%), but none of them achieved $100 \%$ success ratio. All three students who achieved $100 \%$ success were FM students, but surprisingly, the only student who did not have a single correct answer was also student of the FM study program. In terms of comparing economic and transport study programs, EBaM students achieved the second worst results, as on average these students achieved worse results than students of all other study programs except road transport students. For students, whose future job should be business and management, these results are alarming.

Another hypothesis of this research was that women have lower levels of financial literacy than men, and this assumption was confirmed. The success rate of women was on average $7.08 \%$ lower than that of men, the relation was strongly statistically significant. Of all the regression analysis coefficients, the p-value of the GenderFem coefficient was the smallest (less than .001), indicating that the gender factor was the most significant coefficient of all the parameters considered.

These results are consistent with most previous research. Bhushan and Medura (2013) observed that the average score for men was $61.41 \%$ and for women $51.46 \%$, a difference of $9.95 \%$. This difference was statistically significant at the $5 \%$ level of significance. Lusardi et al. (2009) found that women were about 6 percentage points less likely to answer the interest rate question correctly, 15 percentage points less likely to answer the inflation question correctly, and almost 16 percentage points less likely to answer risk diversification question correctly. Ansong and Gyensare, (2012) also showed that female students performed worse than male students. Moreover, they found that male working-students demonstrated higher level of financial literacy than female working-students, with a difference of 7.5 percentage points. Chen and Volpe (2002) also showed statistically significantly higher scores of men with a difference of 7 percentage points. Nevertheless, some research did not prove that the level of financial literacy depended on gender, or even showed the opposite results. Falahati et. al (2011) in their research demonstrated that girls showed better financial management and better spending behavior, while boys had better savings behavior. In contrary to most of other research, female students had, on average, 0.6 percentage points higher score on financial literacy than males in a study of Danes and Hira in 1987. Using ANOVA, Clercq (2009) concluded that the age of students has a significant impact on students' awareness of financial literacy, while gender and the amount of pocket money received by children has no statistically significant impact. These ambiguous results suggest that the lower level of women's financial literacy is not a generally valid fact and that financial literacy programs must also aim to eliminate this inequality.

The latest research hypothesis concerned the impact of the use of banking products on the level of financial literacy of students. Research of Sohn et al. (2012) showed that owning a bank account increased financial literacy by more than $5 \%$. Also, PISA 2015 testing revealed many interesting correlations. For example, a bank account increased financial literacy. Children in the United States, Australia, Belgium, and the Netherlands who held a bank account scored higher than students who did not have a bank account. Ownership of a payment card, compared to a bank account, did not significantly affect the level of financial literacy of students in general. Only in Poland, Chile, Italy, Australia, and Lithuania was the possession of a payment card associated with a higher level of financial literacy.

As almost all FPEDAS students own a bank account, the research was focused on whether the use of other banking products affected the level of financial literacy of students. Six selected banking services were observed in the research, but only two of them - use of internet banking and credit card - had a statistically significant impact on the level of financial literacy. The use of internet banking had a positive impact on the level of financial literacy, while students who stated in the questionnaire that they used a credit card achieved a $6.00 \%$ lower success rate than students who claimed that they did not use it. This relation is statistically significant at the level of significance .05 . These results may seem surprising at first glance. There is no 
Patrik BÖHM, Gabriela BÖHMOVÁ, Viktória ŠIMKOVÁ, Jana GAZDÍKOVÁ. The impact of secondary education on the level of financial literacy: The case of Slovakia

PROBLEMS

OF EDUCATION IN THE $21^{\text {st }}$ CENTURY Vol. 79, No. 1, 2021

obvious evidence why students who did not have credit card should perform better. There is a simple explanation, though. Comparing the number of students who claimed to use one of the two cards, it turns out that 135 students used a credit card and 228 did not use it, while 219 used a debit card and 144 did not. This suggests that most students stated that they used one of the two types of payment cards. In Slovakia, for historical reasons the phrase "credit card" is frequently incorrectly used instead of the phrase "debit card". In most situations these two terms are used interchangeably, even though the credit card can be considered as a type of loan. As in many other states, loan is provided in the Slovak Republic only to people with permanent employment, hence students usually do not have credit cards. It is apparent that most of the students who claimed they used credit card did not understand its concept and did not know the difference between the debit and the credit card. It is therefore understandable that they achieved worse results in financial literacy.

Finally, an overview of the research hypotheses is provided with a conclusion as to whether the hypotheses have been confirmed or not.

- $H_{\text {Math\&FL }}$ : Students with a higher number of mathematics and financial literacy lessons at secondary school have a higher level of financial literacy. This hypothesis was not confirmed. No statistically significant correlation was found.

- $H_{\text {StudyProgram }}$ : Students of study programs EaME, FM, and EBaM have a higher level of financial literacy. This hypothesis was partially confirmed. The highest success rate was achieved by students of the EaME study program, and this difference was statistically significant at the significance level of .01. However, it was not confirmed that the students of the other two economic study programs achieved better results.

- $H_{\text {Gender }}$ : Women achieve lower level of financial literacy than men. The hypothesis was confirmed. The gender coefficient is the most significant coefficient of all considered factors.

- $H_{\text {School\&study }}$ Grammar school students and students with better overall academic results in high school perform better in the field of financial literacy. This hypothesis was confirmed. Students with better academic results in secondary school and students who attended grammar schools achieved better results than other students at the level of significance .05 .

- $H_{\text {UseofBankServices: }}$ The use of selected banking products has a positive impact on the level of financial literacy. This hypothesis was only partially confirmed. The use of internet banking was the only factor where a statistically significant correlation was confirmed at the significance level of .05. For other types of banking services, such an impact was not demonstrated.

\section{Conclusions and Implications}

People who have sufficient financial knowledge can efficiently manage money and know how to manage loans and debts. They know how to evaluate different types of risks and find ways to save money. They often understand the ethical, social, and environmental dimensions of finance, have a long-term vision, and are able to plan. An individual's financial decisions affect his or her future life and standard of living. It is necessary to constantly learn in this area, as the financial market is evolving every day and new products and services are emerging.

Financial literacy, its measurement and education in this area is a current topic. In this research, it is pointed out that there is insufficient financial education in Slovakia. Despite the fact that the National Standard of Financial Literacy has been approved and several institutions deal with this area, the subject of financial literacy is not compulsory in Slovakia at any level of education. From the school's point of view, educating students in the field of financial literacy is voluntary. 
Patrik BÖHM, Gabriela BÖHMOVÁ, Viktória ŠIMKOVÁ, Jana GAZDÍKOVÁ. The impact of secondary education on the level of financial literacy: The case of Slovakia

In recent years, many countries have focused on increasing financial literacy of its citizens. Education starts in elementary school and lasts essentially a lifetime. Among the most important findings of this research is that the number of hours of mathematics and the number of hours of financial literacy in secondary school does not have a statistically significant impact on the level of financial literacy. Therefore, when creating educational programs, the relevant institutions must place emphasis not only on the quantity of education, but especially on its quality - the content of education, its form and education of teachers. As teachers have a great responsibility for educating students in the field of financial literacy, great emphasis must be placed on guiding, educating, and supporting them.

Another important finding of this research is that women performed worse in testing than men. This finding is also confirmed by previous research. The authorities responsible for the financial literacy curriculum should reflect on the cause of these findings and seek to address these differences - perhaps through different approaches to gender education or changing the content of education. Ways to eliminate knowledge differences in financial literacy between men and women are the subject of further research.

In addition, the impact of the study program that students attend at the university on the financial literacy level was tested. There are few studies that have already tested such an impact. Students of the economics study programs are expected to be more interested in economics and have better results in financial literacy tests. However, this hypothesis was only partially confirmed, as EaME students achieved the highest test success, while EBaM students, for example, finished the second worst. These alarming results must be a warning to the faculty management to tighten and possibly change the rules of the admission procedure.

The research tested students who participated in the PISA 2015 test. The results of PISA testing revealed major shortcomings in the area of financial literacy - the great influence of socio-economic and other factors on its level. This research shows that the influence of these factors, such as the gender of the students, was not eliminated during high school. The subject of further research will be whether university education can eliminate these socio-economic impacts.

\section{Acknowledgements}

The present work is supported by the project Modernizing the system of mathematical education with the progressive elements of teaching - 13/PEDAS/2019.

\section{References}

Agnew, S., Maras, P., \& Moon, A. (2018). Gender differences in financial socialization in the home. An exploratory study. International Journal of Consumer Studies, 42(3), 275282. https://doi.org/10.1111/ijcs. 12415

Amagir, A., Groot, W., Brink, H. M. V. D., \& Wilschut, A. (2017). A review of financial-literacy education programs for children and adolescents. Citizenship, Social and Economics Education, 17(1), 5680. https://doi.org/10.1177/2047173417719555

Ansong, A., \& Gyensare, M. A. (2012). Determinants of university working-students' financial literacy at the University of Cape Coast, Ghana. International Journal of Business and Management, 7(9), 126-133. https://doi.org/10.5539/ijbm.v7n9p126

Arthur, C. (2012). Financial literacy education. Neoliberalism, the consumer and the citizen. Sense Publishers. https://doi.org/10.1007/978-94-6091-918-3

Batsaikhan, U., \& Demertzis, M. (2018). Financial literacy and inclusive growth in the European Union. Bruegel. https://www.bruegel.org/2018/05/financial-literacy-and-inclusive-growth-in-theeuropean-union/

Bhushan, P., \& Medury, Y. (2013). Financial literacy and its determinants. International Journal of Engineering, Business and Enterprise Applications, 4, 155-160.

\begin{tabular}{l} 
OF EDUCATION \\
IN THE 21 $1^{\text {st }}$ CENTURY \\
Vol. 79, No. 1, 2021 \\
\hline 31
\end{tabular} 
Patrik BÖHM, Gabriela BÖHMOVÁ, Viktória ŠIMKOVÁ, Jana GAZDÍKOVÁ. The impact of secondary education on the level of financial literacy: The case of Slovakia

PROBLEMS

OF EDUCATION IN THE $21^{\text {st }}$ CENTURY Vol. 79, No. 1, 2021

Blue, L., Grootenboer, P., \& Brimble, M. (2014). Financial literacy education in the curriculum: Making the grade or missing the mark? International Review of Economics Education, 16, 51-62. https://doi.org/10.1016/j.iree.2014.07.005

Brillová, I. (2017). Slovenskí žiaci sú slabo finančne gramotní, ukazujú to testy. [Slovak students are poorly financially literate, tests show]. Financial report. https://www.finreport.sk/financie/ slovenski-ziaci-su-slabo-financne-gramotni-ukazuju-to-testy/?host=8d92e23291e6a66014d4419 ba650c6da

Chen, H., \& Volpe, R. P. (2002). Gender differences in personal financial literacy among college students. Financial Services Review, 11(3), 289-307.

Clercq, B. D. (2009). Do our children know anything about money? An exploratory study. Meditari Accountancy Research, 17(1), 1-13. https://doi.org/10.1108/10222529200900001

Danes, S. M., \& Hira, T. K. (1987). Money management knowledge of college students. Journal of Student Financial Aid, 17, 4-16.

Falahati, L., Babaei, H., \& Paim, L., H. (2011). Ethnic and gender differences in financial management among college students. Journal of American Science, 7(6), 1189 - 1192.

Fox, J., Bartholomae, S., \& Lee, J. (2005). Building the case for financial education. Journal of Consumer Affairs, 39(1), 195-214. https://doi.org/10.1111/j.1745-6606.2005.00009.x

Henningsen, A. (2019). censReg: Censored regression (Tobit) models. R package version 0.5-30. https:// CRAN.R-project.org/package $=$ censReg

Huston, S. J. (2009). Measuring financial literacy. The Journal of Consumer Affairs, 44(2), 296-316. https://doi.org/10.2139/ssrn.1945216

Janakova, H., \& Fabova, L. (2017). Financial literacy of Slovak university graduates. Journal of Knowledge Society, 2, $34-42$.

Kozina, F. L., \& Ponikvar, N. (2014). Students' confidence in their financial management abilities: The role of socio-demographic characteristics and education. Problems of Education in the 21st Century, 58, 108-117. http://www.scientiasocialis.lt/pec/node/886

Lučeničová, K (2015). Finančná gramotnost'v testovaných úlohách. Moderné vzdelávanie pre vedomostnú spoločnost'. [Financial literacy in tested tasks. Modern education for the knowledge society]. http://www.etest.sk/data/att/582.pdf

Lusardi, A. (2004). Saving and the effectiveness of financial education. In Mitchell, O., \& S. Utkus (Eds.), Pension design and structure: New lessons from behavioral finance (pp. 157-184). Oxford University Press. https://doi.org/10.1093/0199273391.003.0009

Lusardi, A., Mitchell, O. S., \& Curto, V. (2009). Financial literacy among the young. The Journal of Consumer Affairs, 44(2), 358-380.

Mandell, L. (2006). Financial literacy: If it's so important, why isn't it improving? NFI Policy Briefs, Indiana State University, Scott College of Business, Networks Financial Institute.

NBS (2019). The financial literacy support strategy of Národná banka Slovenska. 2019. https://www. nbs.sk/_img/Documents/_TS/191107/final_nbs_strategiaFinGram_en.pdf

OECD (2011). Improving financial education efficiency: OECD Bank of Italy symposium of financial literacy. OECD Publishing, Paris. https://doi.org/10.1787/9789264108219-en

OECD (2015). Women and financial literacy OECD/INFE Evidence, survey and policy responses. http:// www.oecd.org/daf/fin/financial-education/TrustFund2013_OECD_INFE_Women_and_Fin_Lit. pdf

OECD (2014). PISA 2012 results: Students and money (Volume VI): Financial literacy skills for the 21st century. PISA, OECD Publishing, Paris. https://doi.org/10.1787/9789264208094-en

OECD (2017). PISA 2015 results (Volume IV): Students' financial literacy. PISA, OECD Publishing, Paris. https://doi.org/10.1787/9789264270282-en

OECD (2020). PISA 2018 results (Volume IV): Are students smart about money? PISA, OECD Publishing, Paris. https://doi.org/10.1787/48ebd1ba-en

R Core Team (2013). R: A language and environment for statistical computing. R foundation for statistical computing. Vienna, Austria. http://www.R-project.org/

Rudeloff, M. (2019). The influence of informal learning opportunities on adolescents' financial literacy. Empirical Research in Vocational Education and Training, 11(1). https://doi.org/10.1186/s40461019-0086-y 
Patrik BÖHM, Gabriela BÖHMOVÁ, Viktória ŠIMKOVÁ, Jana GAZDÍKOVÁ. The impact of secondary education on the level of financial literacy: The case of Slovakia

PROBLEMS

OF EDUCATION

IN THE $21^{\text {st }}$ CENTURY

Vol. 79, No. 1, 2021

Sabri, M. F., Macdonald, M., Hira, T. K., \& Masud, J. (2010). Childhood consumer experience and the financial literacy of college students in Malaysia. Family and Consumer Sciences Research Journal, 38(4), 455-467. https://doi.org/10.1111/j.1552-3934.2010.00038.x

Sachitra, V., \& Wijesinghe, D. (2018). What determine money management behaviour of undergraduates? An examination in an emerging economy. Journal of Education, Society and Behavioural Science, 26(4), 1-14. https://doi.org/10.9734/jesbs/2018/44050

Schleicher, A. (2018). PISA 2018: Insights and interpretations. OECD Publishing. https://eric. ed.gov/?id=ED601150

SLSP (2020). Slovenská sporitel’ňa Foundation. Vzdelávanie. [Education]. https://www.slsp.sk/sk/ nadacia/podporujeme/vzdelavanie

Sohn, S.-H., Joo, S.-H., Grable, J. E., Lee, S., \& Kim, M. (2012). Adolescents' financial literacy: The role of financial socialization agents, financial experiences, and money attitudes in shaping financial literacy among South Korean youth. Journal of Adolescence, 35(4), 969-980. https://doi.org/10.1016/j.adolescence.2012.02.002

The World Bank (2020). Universal financial access by 2020. https://www.worldbank.org/en/topic/ financialinclusion/brief/achieving-universal-financial-access-by-2020

White, K. R. (1982). The relation between socioeconomic status and academic achievement. Psychological Bulletin, 91(3), 461-481. https://doi.org/10.1037/0033-2909.91.3.461

Willis, L. E. (2008). Against financial literacy education. Faculty Scholarship at Penn Law. https://scholarship.law.upenn.edu/faculty_scholarship/199/

Received: November 23, 2020

Accepted: February 02, 2021

Cite as: Böhm, P., Böhmová, G., Šimkova, V., \& Gazdikova, J. (2021). The impact of secondary education on the level of financial literacy: The case of Slovakia. Problems of Education in the $21^{\text {st }}$ Century, 79(1), 13-33. https://doi.org/10.33225/pec/21.79.13

\begin{tabular}{|c|c|}
\hline $\begin{array}{l}\text { Patrik Böhm } \\
\text { (Corresponding author) }\end{array}$ & $\begin{array}{l}\text { Mgr, PhD, Lecturer, Department of Quantitative Methods and Economic } \\
\text { Informatics, Faculty of Operation and Economics of Transport and } \\
\text { Communications, University of Zilina, Slovakia. } \\
\text { E-mail: patrik.bohm@fpedas.uniza.sk } \\
\text { ORCID: https://orcid.org/0000-0002-3210-1055 }\end{array}$ \\
\hline Gabriela Böhmová & $\begin{array}{l}\text { Mgr, PhD, Lecturer, Department of Quantitative Methods and Economic } \\
\text { Informatics, Faculty of Operation and Economics of Transport and } \\
\text { Communications, University of Zilina, Slovakia. } \\
\text { E-mail: gabriela.bohmova@fpedas.uniza.sk } \\
\text { ORCID: https://orcid.org/0000-0001-6416-4352 }\end{array}$ \\
\hline Viktória Šimková & $\begin{array}{l}\text { Ing, PhD, Lecturer, Department of Quantitative Methods and Economic } \\
\text { Informatics, Faculty of Operation and Economics of Transport and } \\
\text { Communications, University of Zilina, Slovakia. } \\
\text { E-mail: viktoria.simkova@fpedas.uniza.sk } \\
\text { ORCID: https://orcid.org/0000-0003-3571-3505 }\end{array}$ \\
\hline Jana Gazdíková & $\begin{array}{l}\text { Mgr, PhD, Lecturer, Department of Quantitative Methods and Economic } \\
\text { Informatics, Faculty of Operation and Economics of Transport and } \\
\text { Communications, University of Zilina, Slovakia. } \\
\text { E-mail: jana.gazdikova@fpedas.uniza.sk } \\
\text { ORCID: https://orcid.org/0000-0001-6999-0880 }\end{array}$ \\
\hline
\end{tabular}

